\title{
A meta-analysis of changes in soil organic carbon stocks after afforestation with deciduous broadleaved, sempervirent broadleaved, and conifer tree species
}

\author{
Guolong Hou ${ }^{1} \cdot$ Claudio O. Delang $^{1}$ (D) Xixi Lu $^{2,3} \cdot$ Lei Gao $^{2}$ \\ Received: 25 March 2020 / Accepted: 1 September 2020 / Published online: 25 September 2020 \\ (C) INRAE and Springer-Verlag France SAS, part of Springer Nature 2020
}

\begin{abstract}
- Key message Different tree species have dissimilar capacities to sequester soil organic carbon (SOC). Deciduous broadleaved trees show the most stable increase in SOC stock after afforestation than other tree species, while sempervirent conifer trees show the lowest rate of SOC stock change. Sempervirent broadleaved trees show the greatest increase in SOC stock 20 years after afforestation.

- Context The rate at which soil organic carbon (SOC) stock changes after afforestation varies considerably with the tree species. A better understanding of the role of tree species in SOC change dynamic is needed to evaluate the SOC sequestration potential of afforestation programs.

- Aims The aim of this paper is to identify the dissimilar rates at which different tree species sequester SOC, following afforestation.

- Methods We complete a meta-analysis with 544 data points from 261 sites in 90 papers. We group tree species into decidious broadleved, sempervirent broadleaved and sempervirent conifer. We use standardization and/or extrapolation methods to standardize soil depths. Statistical analysis test the main effects of tree species and their interactions with previous land use and plantation age on SOC stock change after afforestation.

- Results Deciduous broadleaved trees show a stable increase in SOC stock, and are especially suited for afforestation of grassland or soils with high initial SOC. Sempervirent broadleaved afforestation results in loss of SOC stock in young stands, but greater SOC stock in mature stands. Sempervirent conifer trees show the lowest rate of SOC stock change, but are suitable for nutrient-poor soil.

- Conclusion The results emphasize the importance of considering tree species when estimating SOC stock change, in particular when carbon sequestration is an objective of afforestation programs.
\end{abstract}

Keywords Soil organic carbon stock change $\cdot$ Afforestation $\cdot$ Deciduous broadleaved $\cdot$ Sempervirent broadleaved $\cdot$ Sempervirent conifer

Handling Editor: Ana Rincón

Electronic supplementary material The online version of this article (https://doi.org/10.1007/s13595-020-00997-3) contains supplementary material, which is available to authorized users.

Claudio O. Delang

cdelang@hkbu.edu.hk

Guolong Hou

gwoklung@gmail.com

Xixi Lu

geoluxx@nus.edu.sg

Lei Gao

leigao.nmgdx@qq.com
1 Department of Geography, Hong Kong Baptist University, Kowloon Tong, Hong Kong SAR, China

Inner Mongolia Key Lab of River and Lake Ecology, School of Ecology and Environment, University of Inner Mongolia, Hohhot 010021, China

3 Department of Geography, National University of Singapore, 1 Arts Link, Kent Ridge, Singapore 117570, Singapore 


\section{Introduction}

The soil organic carbon (SOC) pool plays an important role in maintaining soil structure and aggregation, making soils less prone to degradation (Lal 2006). However, abuses of the soil system, such as continuous farming, have resulted in the depletion of the SOC pool, which is a principal cause of soil degradation (Lal 2015). While it is generally acknowledged that afforestation can increase SOC stocks and alleviate soil degradation, there are many factors influencing the changes in SOC stock after afforestation such as previous land use (cropland or grassland), plantation age, tree species, soil depths and climatic conditions (Guo and Gifford 2002; Laganiere et al. 2010; Poeplau et al. 2011; Bárcena et al. 2014).

Previous land use can significantly affect SOC stock change dynamics after afforestation. The practice of tillage on cropland accelerates the decomposition of SOC (Laganiere et al. 2010). Therefore, afforestation generally leads to an increase in SOC stock on cropland (Guo and Gifford 2002; Laganiere et al. 2010; Poeplau et al. 2011; Hou et al. 2019a). However, the permanent vegetation cover and a high density of fine roots of grassland contribute to a higher SOC stock than cropland (Bárcena et al. 2014). There is a lack of consensus among researchers regarding the changing dynamics of SOC in afforested grassland. For example, a decrease of SOC stocks following afforestation on grassland is found in Guo and Gifford's (2002), Poeplau et al.'s (2011) and Bárcena et al.'s (2014) studies, but the opposite results are obtained by Laganiere et al. (2010) and Don et al. (2011). Unfortunately, the reasons behind such inconsistencies remain undiscussed in the literature.

Plantation age is another contributor to SOC stock change. There is general agreement that SOC stock initially drops following afforestation due to soil disturbance during the initial stage of land use conversion ( $\mathrm{Li}$ et al. 2012). However, findings differ among studies about the long-term SOC stock change. Some studies (e.g. Paul et al. 2002; Luyssaert et al. 2008; Laganiere et al. 2010; Li et al. 2012) showed that SOC continues to drop during the first 10-15 years of afforestation, but increases significantly 30-50 years after afforestation. On the other hand, Nave et al. (2013) reported that 15 years are sufficient to detect a significant increase in SOC contents following afforestation, while Song et al. (2014) found that 1620 years are sufficient. Newly planted or regenerating forests, in the absence of major disturbances, will continue to uptake soil carbon for 20 to 50 years or more after establishment, depending on tree species and site conditions (IPCC 2007). However, how and to what extent the effects of plantation age on SOC dynamics can be influenced by different tree species and site conditions is not well understood.

Tree types play an important role in SOC stock changes after afforestation, because forest litter (aboveground and belowground) is a major component of soil organic matter input
(Gill and Jackson 2000; Cornwell et al. 2008; Olsson et al. 2019). Different tree types not only have different litter production, but their litter decomposition rates also differ (Cao et al. 2020) and both contribute to SOC stock change dynamics. A better understanding of the role of tree types in SOC stock changes is necessary for the evaluation of SOC sequestration potential (Hou et al. 2019a). Unfortunately, there will never be a perfect way to group trees. Previous studies usually divided trees into hardwood and softwood (Paul et al. 2002; Li et al. 2012) or conifers and broadleaved (Bárcena et al. 2014; Hou et al. 2020). However, overlaps may occur because species such as Larix could be considered both conifers and deciduous and species such as Eucalyptus could be viewed as both broadleaf and sempervirent. In addition, broadleaved trees are usually deciduous in temperate and boreal latitudes, but sempervirent in the tropics and subtropics. SOC input from litterfall of different broadleaved trees could also be substantially different, which changes the SOC dynamics (De Deyn et al. 2008; Pérez-Cruzado et al. 2012). Broadleaved litter is faster decomposable than coniferous litter because the former contains less lignin (Lukac and Godbold 2011). The litter decomposition rate is also related to the form and structure of the foliage (Olsson et al. 2019). Litterfall of sempervirent trees generally decompose more slowly than that of deciduous trees (Cornwell et al. 2008). On the other hand, the ways in which SOC dynamics differ between deciduous broadleaved trees and sempervirent broadleaved trees are less understood. The present authors suggest a synthesis that classifies tree species as (i) deciduous broadleaved, (ii) deciduous conifer, (iii) sempervirent broadleaved and (iv) sempervirent conifer (Hou et al. 2020b). This classification has the advantage that (i) some overlaps can be avoided, and (ii) there will be fewer variations within each tree type. Deciduous conifer trees are not included in our study as insufficient studies have reported SOC-related information about this tree type.

Different vegetation covers have different root depths. The fine root systems of crops and grasses are mainly concentrated in the $0-20 \mathrm{~cm}$ soil depth, while most tree root systems are found at depths of up to $60 \mathrm{~cm}$ (Di Iorio et al. 2005; Li et al. 2017). Agricultural mechanical practices such as ploughing usually disturb soil up to a depth of $40 \mathrm{~cm}$, which increases the decomposition rate of SOC (Angers and Eriksen-Hamel 2008). Since the allocation of root biomass drives the vertical distribution of SOC (Di Iorio et al. 2005), it is to be expected that (1) agricultural mechanical practices affect SOC differently at different soil depths, and (2) afforestation may have a different impact on SOC dynamics at different soil depths (Hou et al. 2019a). Unfortunately, many studies do not provide SOC measurements for different soil depths. Some studies (e.g. Zhang et al. 2010; Bárcena et al. 2014; Deng et al. 2014; Liu et al. 2017) only examined soil depths of 0-20/30 cm, while others (e.g. Post and Kwon 2000; Laganiere et al. 2010; Don et al. 2011; Poeplau et al. 2011) only reported 
mean sampling depth. This is insufficient to determine SOC change dynamics for deeper soil, or to compare such changes among different soil depths. Both soil depth and tree type should be considered when estimating soil carbon changes. As such, there is a gap in knowledge about how and to what extent the SOC stock changes at different soil depths.

Climatic conditions such as temperature, precipitation and climatic zones can influence the growth of vegetation and the SOC decomposition rate (Lal 2018). In boreal climate zones, trees have a slower growth rate, a lower production of litterfall and a slower decomposition of litter, all of which contribute to a lower SOC input (Laganiere et al. 2010; Ge et al. 2017). While temperature tends to negatively affect the SOC stock, studies hold different ideas about the relationship between precipitation and the SOC stock. For example, a negative effect of precipitation was detected by Zhang et al. (2010), whereas a positive effect was documented by Shi et al. (2013). This inconsistency may be due to the interaction effects between leaf habit (deciduous broadleaved trees versus sempervirent broadleaved trees) and climate on the decomposition of leaf litter (Ge et al. 2017). Climate sensitivities of leaf litter decomposition vary across tree types. Mean annual temperature plays a major role in the leaf litter decomposition of sempervirent broadleaved trees, whereas mean annual precipitation mainly influences the leaf litter decomposition of deciduous broadleaved trees (Ge et al. 2017).

Studies have mainly focused on the influences of common contributing factors, including previous land use, tree species, plantation age and climatic conditions, on SOC stocks and change dynamics, with little attention to the interactions among different factors. However, these interactions may change the effects of afforestation on SOC change dynamics (Jobbágy and Jackson 2000; Bárcena et al. 2014). For example, Eclesia et al. (2012) argue that, to some extent, SOC losses in humid sites are counterbalanced by the effect of plantation age. Nevertheless, the interactions have been insufficiently investigated.

The objectives of this paper are (1) to investigate the effects of tree species (grouped as deciduous broadleaved, sempervirent broadleaved or sempervirent conifer) on SOC stock changes; (2) to assess the interactions between tree species, previous land use and plantation age on SOC stock changes; (3) to detect the main factors influencing the SOC stock changes after afforestation with different tree species in three soil depths (0-20 cm, 20-40 cm, 40-60 cm). To avoid interactions among different species, we only consider monocultures in this study (Stockmann et al. 2013). Our findings will contribute to a better understanding of SOC stocks and dynamics following afforestation, and will enable policymakers and landowners to choose the right tree species to replant deforested land.

\section{Materials and methods}

\subsection{Data sources and compilation}

The academic articles included in this meta-analysis were retrieved by searching Google Scholar and the Web of Science with the keywords "afforestation" and "soil organic carbon" (cut-off date: 1 July 2018). This meta-analysis includes refereed articles which fulfil the following conditions. First, the studies had to either report the SOC value from soil depths of $0-20 \mathrm{~cm}, 20-40 \mathrm{~cm}$ or $40-60 \mathrm{~cm}$, or at least three SOC stock data at different depths, so that we can extrapolate the missing values (see below). Second, the study had to include a description of the land use history and provide the initial SOC stocks before afforestation or the SOC stocks of nearby nonforested sites. Third, the papers had to identify the planted tree species, plantation age and sampling depth. We only collected data from afforestation sites with single (not mixed) species to avoid interactions among different species. Tree species included as deciduous broadleaved, sempervirent broadleaved or sempervirent conifer trees types are showed in Table 1. Articles that dealt with both reforestation and afforestation are included in this study (IPCC 2007).

We reviewed over 300 studies and the final dataset comes from 90 peer-reviewed academic articles published between 1990 and 2018, and consists of 261 sites, including 261 topsoils $(0-20 \mathrm{~cm})$ and a large number of subsoils (168 from 20 $40 \mathrm{~cm}$ and 115 from $40-60 \mathrm{~cm}$ ). Figure 1 shows the geographic distribution of the study sites. Apart from SOC data, tree species, plantation age, soil sampling depth and soil bulk density, for each site, we recorded all geographical and climatic information, namely latitude, longitude, mean annual temperature and precipitation. If values for temperature or precipitation were missing, we obtained them from the records of nearby weather stations using www.weatherbase.com (Poeplau et al. 2011). Soil taxonomic order is not used in this study because soil texture is not reported in most studies reviewed here. Detailed site information and dataset used in this metaanalysis are shown in Annex 1.

\subsection{SOC estimation}

Units of soil carbon stocks used in the literature, such as "kg $\mathrm{m}^{-2}$ ", " $\mathrm{g} \mathrm{m}^{-2}$ ", " $\mathrm{kg} \mathrm{ha} \mathrm{h}^{-1}$ " and "t ha ${ }^{-1}$ ", were transformed to "Mg ha ${ }^{-1}$ ". If there was no direct report of SOC stock in the study, we used the percentage of SOC concentration or C accumulation, bulk density and sampling depth to calculate SOC stock. If the samples only reported soil organic matter (SOM) content, the SOC values were calculated using the relationship between SOM and SOC (Mann 1986):

$$
\mathrm{SOC}=\mathrm{SOM} \times \mathrm{O} .58
$$


Table 1 Tree species included as deciduous broadleaved, sempervirent broadleaved or sempervirent conifer

\begin{tabular}{|c|c|}
\hline & Species \\
\hline Deciduous broadleaved & $\begin{array}{l}\text { Caragana Korshinskii Kom. } \\
\text { Caragana microphylla Lam. } \\
\text { Populus davidiana Dode } \\
\text { Populus deltoides W. Bartram ex Marshall. } \\
\text { Populus euphratica Oliv. } \\
\text { Populus simonii Carrière } \\
\text { Populus tomentosa } \\
\text { Robinia pseudoacacia } \text { L. }\end{array}$ \\
\hline $\begin{array}{l}\text { Sempervirent } \\
\text { broadleaved }\end{array}$ & $\begin{array}{l}\text { Eucalyptus camaldulensis Dehnh. } \\
\text { Eucalyptus globulus Labill. } \\
\text { Eucalyptus grandis W. Hill } \\
\text { Eucalyptus gunnii Hook.f. } \\
\text { Eucalyptus nitens (H. Deane \& Maiden) } \\
\quad \text { Maiden } \\
\text { Eucalyptus saligna Sm. } \\
\text { Eucalyptus urophylla S.T. Blake }\end{array}$ \\
\hline Sempervirent conifer & $\begin{array}{l}\text { Chamaecyparis obtuse (Siebold \& Zucc.) } \\
\text { Endl. } \\
\text { Cupressus funebris Endl. } \\
\text { Cupressus lusitanica Mill. } \\
\text { Cupressus macrocarpa Hartw. } \\
\text { Pinus caribaea Morelet } \\
\text { Pinus densiflora Siebold \& Zucc. } \\
\text { Pinus elliottii Engelm. } \\
\text { Pinus halepensis Mill. } \\
\text { Pinus massoniana Lamb. } \\
\text { Pinus nigra J.F. Arnold } \\
\text { Pinus palustris Mill. } \\
\text { Pinus patula Schiede ex Schltdl. \& Cham. } \\
\text { Pinus ponderosa Douglas ex C. Lawson } \\
\text { Pinus radiata D.Don } \\
\text { Pinus resinosa Sol. ex Aiton } \\
\text { Pinus strobus L. } \\
\text { Pinus sylvestris L. } \\
\text { Pinus taeda L. } \\
\text { Pinus tabuliformis Carr. } \\
\text { Pinus virginiana Mill. }\end{array}$ \\
\hline
\end{tabular}

Bulk density (BD) is necessary to calculate the amount of SOC stock, and can also affect the rate of SOC stock changes (Don et al. 2011; Deng et al. 2014). However, until now, to our knowledge, no soil BD estimating model has been adjusted for soil depth, which may have resulted in the underestimation of SOC stock changes after afforestation (Post and Kwon 2000; Don et al. 2011). Studies have confirmed the strong relationship between SOC content and $\mathrm{BD}$ value (Bormann and Klaassen 2008; Sakin 2012). A global estimate of SOC stock also lists SOC content as the only parameter to estimate the missing $\mathrm{BD}$ value for organic soil (Hiederer and Köchy 2011). In the present study, missing BD values are from organic soil in China; therefore, they are estimated using Wu et al. (2003):

$$
\begin{aligned}
& \mathrm{BD}=-0.1229 \ln (\mathrm{SOC})+1.2901(\text { for } \mathrm{SOC}<6 \%) \\
& \mathrm{BD}=1.3774 e^{-0.0413 \mathrm{SOC}}(\text { for } \mathrm{SOC}>6 \%)
\end{aligned}
$$

As plantation age plays an important role in the amount of SOC change, we calculate the rate of SOC changes (Xiong et al. 2014). The SOC stock, SOC stock change $(\Delta C s)$ and $\Delta \mathrm{Cs}$ rate were calculated using the following equations:

$$
\begin{aligned}
& \mathrm{Cs}=\frac{\mathrm{SOC} \times \mathrm{BD} \times \mathrm{D}}{10} \\
& \Delta \mathrm{Cs}=\mathrm{Cse}-\mathrm{Csc} \\
& \Delta \mathrm{Cs} \text { rate }=\frac{\Delta \mathrm{Cs}}{\mathrm{A}}
\end{aligned}
$$

where $\mathrm{Cs}$ is the SOC stock $\left(\mathrm{Mg} \mathrm{ha}^{-1}\right), \Delta \mathrm{Cs}$ rate is the rate of SOC changes ( $\mathrm{Mg} \mathrm{ha}^{-1}$ year $\left.{ }^{-1}\right)$, SOC is SOC concentration ( $\mathrm{g}$ $\left.\mathrm{kg}^{-1}\right)$, BD is soil bulk density $\left(\mathrm{g} \mathrm{cm}^{-3}\right), \mathrm{D}$ is soil depth $(\mathrm{cm})$, Cse is the mean SOC stock in afforested sites $\left(\mathrm{Mg} \mathrm{ha}^{-1}\right)$, Csc is the mean $\mathrm{SOC}$ in the adjacent compared sites $\left(\mathrm{Mg} \mathrm{ha}^{-1}\right)$ and $\mathrm{A}$ is plantation age (year).

\subsection{Soil depth standardization and extrapolation}

Two sets of data reported in the reviewed literature did not conform to our classification, and we had to estimate the missing data. First, in 151 cases, we standardized soil depths, because soil depth intervals vary among studies. For example, some studies measure carbon at soil depths of $5 \mathrm{~cm}, 10$ $\mathrm{cm}, 30 \mathrm{~cm}$ and $60 \mathrm{~cm}$, while some at much broader depths of 0-30 cm, 0-60 cm and 0-100 cm. In such cases, SOC data were converted from different depths, e.g. $0-5 \mathrm{~cm}, 5-10 \mathrm{~cm}$, $10-30 \mathrm{~cm}$ and $30-60 \mathrm{~cm}$, into standard depths $0-20 \mathrm{~cm}, 20$ $40 \mathrm{~cm}$ and $40-60 \mathrm{~cm}$. We performed paired sample $T$ tests to evaluate the accuracy of each site's polynomial trend lines (order 2) with the observed data, but found no significant differences between estimated and actual data $(P=0.92, n$ $=368$ ).

Second, in 61 cases ( $11 \%$ of the total), we had to estimate SOC data for the $20-40 \mathrm{~cm}$ or $40-60 \mathrm{~cm}$ depths. We only did this if the original data fulfilled the following requirements: (1) the study reported at least three original SOC stock data from three different soil depths; (2) if we estimated the data for the 40-60 cm depth, the deepest soil depth with reported SOC values had to be no less than $40 \mathrm{~cm}$. For example, if we only have $0-10 \mathrm{~cm}, 10-20 \mathrm{~cm}$ and $20-30 \mathrm{~cm}$ depths, we estimate 


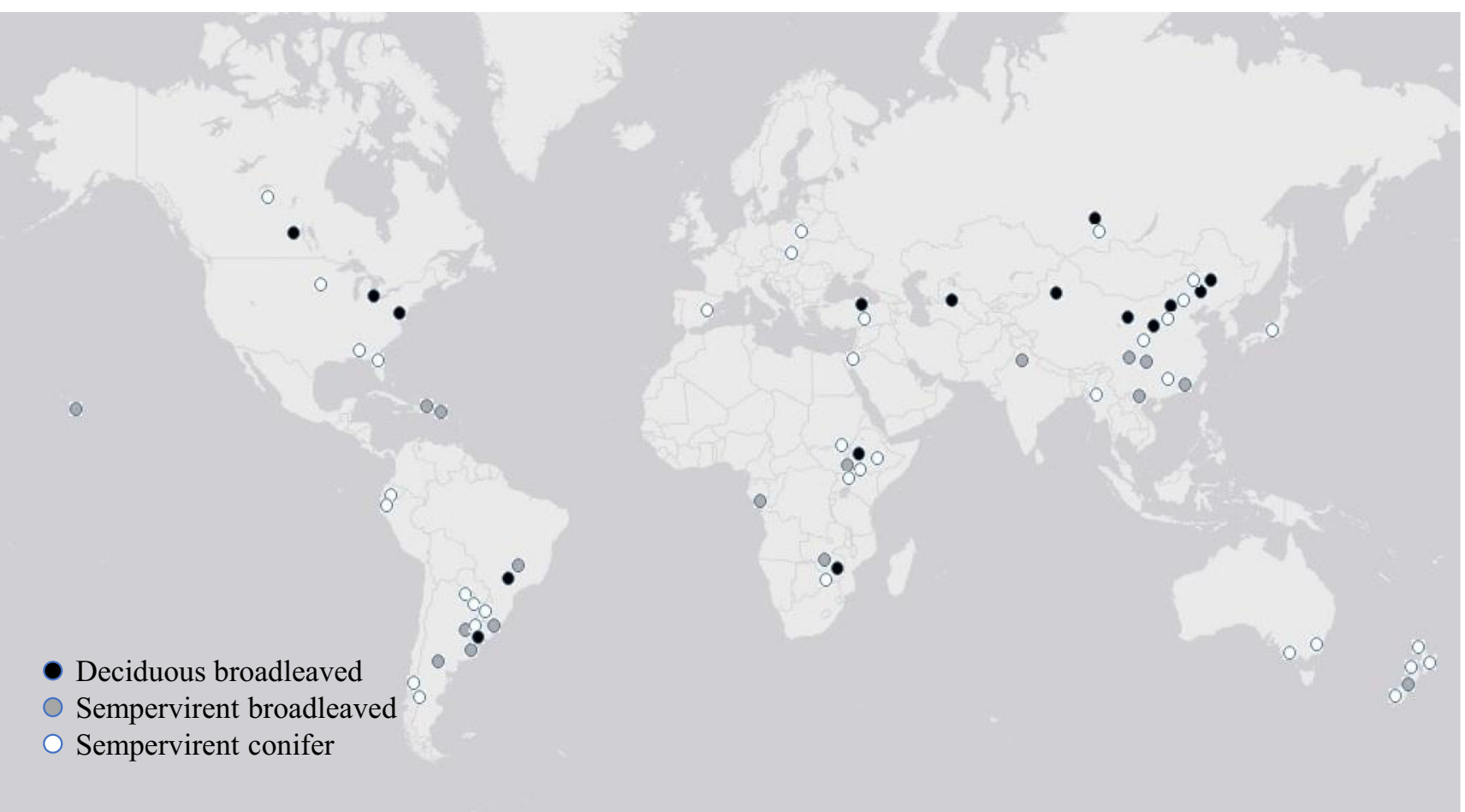

Fig. 1 Location of the study sites in this meta-analysis

the $0-20 \mathrm{~cm}$ and $20-40 \mathrm{~cm}$ depth, but not the $40-60 \mathrm{~cm}$ depth. Detailed explanation of the standardization and extrapolation methods is described in Annex 2.

\subsection{Statistical analysis}

Before proceeding with the data analysis, all variables were examined for normality. We performed a two-way analysis of variance (ANOVA) to test the effects of tree species (grouped as deciduous broadleaved, sempervirent broadleaved or sempervirent conifer), and its interaction with previous land use and plantation age groups on the rate of SOC stock change. Differences were evaluated at the 0.05 significance level. Significant differences were evaluated at the 0.05 level using the least significant difference (LSD) post hoc test. The impacts of afforestation on changes in SOC stock were considered significant if the 95\% confidence intervals did not overlap with zero. We used stepwise regression analysis to analyse the relationship between $\Delta$ Cs following afforestation and mean annual temperature $(\mathrm{T})$, mean annual precipitation $(\mathrm{P})$, plantation age (A) and initial Cs (I) for different tree species. We used Pearson correlation analysis to study the relationship between rates of SOC stock change following afforestation and $\mathrm{T}, \mathrm{P}$ and $\mathrm{I}$ of all data. All statistical analyses were performed using SPSS, version 25.0 (SPSS Inc., Chicago, IL, USA).

\section{Results}

\subsection{Changes in SOC stocks for different tree species}

Deciduous broadleaved species are the only tree species that show positive rates of SOC stock change across three soil depths, and they are significantly higher than zero (Fig. 2). The highest rate of SOC stock change also occurs in deciduous broadleaved tree species throughout all soil depths with significant differences in the topsoil. However, the differences among the rates of SOC stock change of these three tree species shrink with increased soil depth, and there are no significant differences in the $40-60 \mathrm{~cm}$ depth (Fig. 2). Surprisingly, sempervirent conifer trees have a negative rate of SOC stock change, although it is not significantly different from zero. For sempervirent broadleaved tree species, the land SOC dynamics change irregularly across soil depths (Fig. 2).

\subsection{Interactions of tree species, previous land use and plantation age}

ANOVA analysis shows that the interaction of tree species and previous land use have significant influences $(P<$ $0.001)$ on rates of SOC stock change in the topsoil depth (Table 2). The main effects of tree species $(P<0.05)$ and plantation age group $(P<0.01)$ are significant, while their interaction is not significant. In the $20-40 \mathrm{~cm}$ soil depth, only tree species have a significant effect on the rate of SOC stock 
Fig. 2 The rate of SOC stock change of different tree species at different soil depths. Note: Dots with error bars denote the overall rate of SOC stock change and the 95\% confidence interval. Sampling depths $(0-20 \mathrm{~cm}, 20$ $40 \mathrm{~cm}$ and $40-60 \mathrm{~cm}$ ) are indicated. The number of observations is indicated in parentheses. A different letter at the top of the bars indicates a difference significant at the $P<0.05$ level

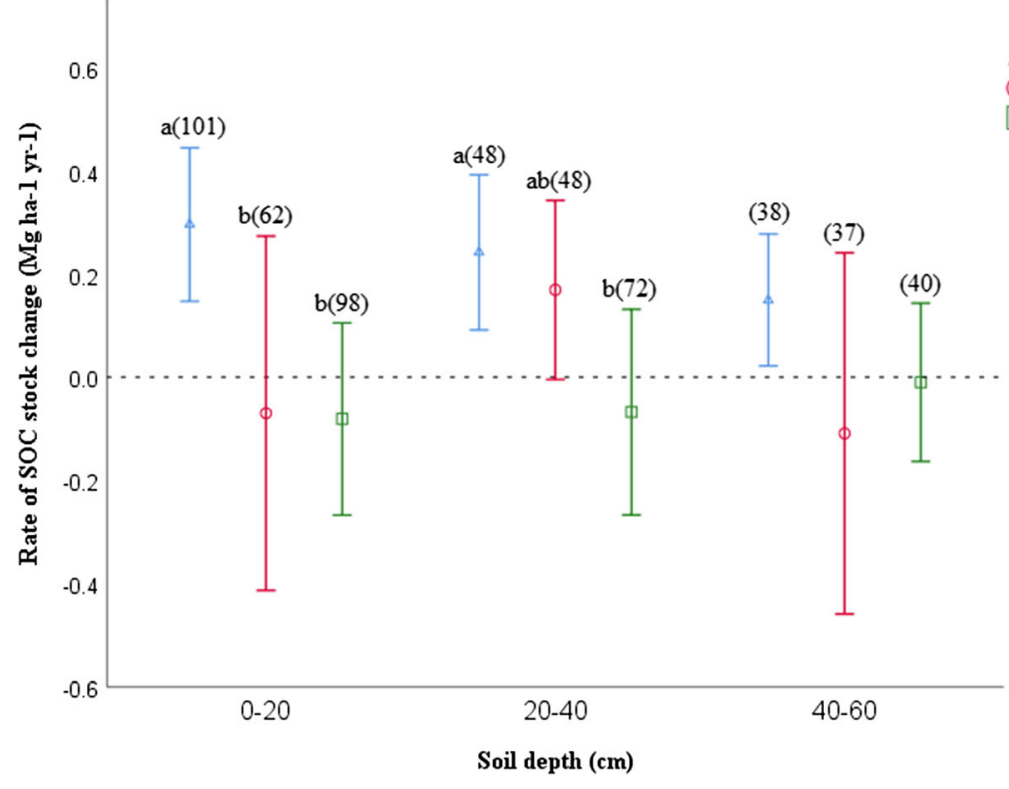

Tree species

$\triangle$ Deciduous broadleaved

Sempervirent broadleaved

Sempervirent conifer

I Deciduous broadleaved

I Sempervirent broadleaved

I Sempervirent conifer change $(P<0.05)$, while plantation age groups have a significant effect in the $40-60 \mathrm{~cm}$ soil depth $(P<0.05)$. Overall, the main effects and interactions of these factors mostly show significant results in the topsoil.

Figure 3a shows the rate of SOC stock change of different tree species after cropland afforestation. Only deciduous broadleaved trees have a positive rate of SOC stock change and are significantly higher than zero across the three soil depths. Sempervirent conifer trees have a significantly greater rate of SOC stock change than sempervirent broadleaved trees in the $0-20 \mathrm{~cm}$ soil depth. However, there are no significant changes in SOC stock in deeper soil after afforestation for sempervirent conifer trees. In contrast, afforesting cropland with sempervirent broadleaved trees results in an increase in SOC stock in the deeper soil depth $(20-40 \mathrm{~cm})$, and the rate of SOC stock change is significantly higher than zero.

On the other hand, SOC dynamics seem different for grassland afforestation, especially for afforestation with sempervirent trees (Fig. 3b). In the $0-20 \mathrm{~cm}$ soil depth, sempervirent conifer trees have a significantly lower rate of SOC stock change than sempervirent broadleaved trees compared with a significantly higher rate in the case of cropland afforestation. In the $20-40 \mathrm{~cm}$ soil depth, sempervirent conifer trees have a significantly lower rate of SOC stock change than deciduous broadleaved trees compared with insignificant differences in the case of cropland afforestation. In the 40-60 cm soil depth, sempervirent broadleaved trees have a negative rate of SOC stock change, compared with a positive rate in the case of cropland, and they are significantly different. The results indicate that the direction and magnitude of SOC stock change is influenced by interactions between previous land uses and tree species.

With each tree species, the capacity to sequester SOC varies among soil depths and with time (Fig. 4). For the 0 $20 \mathrm{~cm}$ soil depth, deciduous broadleaved trees show a continuous positive rate of SOC stock change during the whole period, which is significantly different from zero after the first

Table 2 Two-way ANOVA analysis of tree species, previous land uses and age groups on the rate of SOC stock change in the $0-60 \mathrm{~cm}$ soil depth

\begin{tabular}{|c|c|c|c|c|c|c|c|}
\hline Source & df & $\begin{array}{l}0-20 \mathrm{~cm} \\
\mathrm{~F}\end{array}$ & Sig. & $\begin{array}{l}20-40 \mathrm{~cm} \\
\mathrm{~F}\end{array}$ & Sig. & $\begin{array}{l}40-60 \mathrm{~cm} \\
F\end{array}$ & Sig. \\
\hline TS & 2 & 1.39 & 0.251 & 4.608 & $0.011 *$ & 1.068 & 0.347 \\
\hline PLU & 1 & 2.437 & 0.12 & 0.121 & 0.729 & 0.243 & 0.623 \\
\hline TS.PLU & 2 & 9.511 & $0.0001 * * *$ & 1.868 & 0.158 & 2.646 & 0.075 \\
\hline TS & 2 & 4.506 & $0.012 *$ & 3.385 & $0.036^{*}$ & 1.255 & 0.289 \\
\hline $\mathrm{AG}$ & 3 & 4.786 & $0.003 * *$ & 2.577 & 0.056 & 2.794 & $0.044 *$ \\
\hline $\mathrm{TS} \cdot \mathrm{AG}$ & 6 & 1.969 & 0.071 & 1.238 & 0.29 & 1.068 & 0.347 \\
\hline
\end{tabular}

$d f$, degree of freedom; TS (tree species), deciduous broadleaved, sempervirent broadleaved or sempervirent conifer; $P L U$ (previous land use), cropland and grassland; $A G$ (age group), $0-10$ years, $11-20$ years, $21-30$ years and $31+$ years

$*, * *$ and $* * *$ indicate significant difference at the 0.05 level $(P<0.05), 0.01$ level $(P<0.01)$ and 0.001 level $(P<0.001)$, respectively 
Fig. 3 The rate of SOC stock change of different tree species for $\mathbf{a}$ cropland afforestation and $\mathbf{b}$ grassland afforestation. Note: Dots with error bars denote the overall rate of SOC stock change and the $95 \%$ confidence interval. Sampling depths $(0-20 \mathrm{~cm}, 20$ $40 \mathrm{~cm}$ and $40-60 \mathrm{~cm}$ ) are indicated. The number of observations is indicated in parentheses. A different letter at the top of the bars indicates a difference significant at the $P<0.05$ level

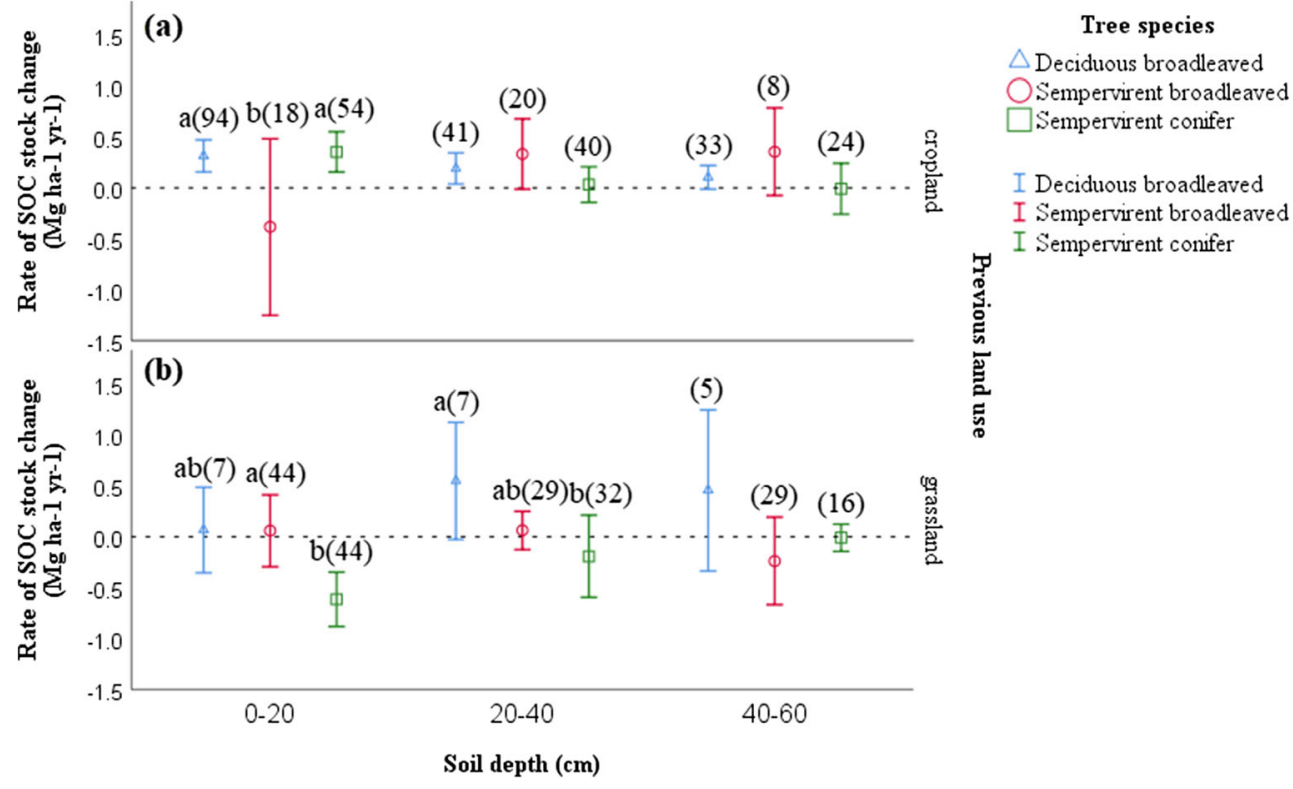

decade (Fig. 4a). Sempervirent broadleaved trees show an upward trend of the rate of SOC stock change, which is significantly greater than that of deciduous broadleaved trees during the third decade after afforestation. Sempervirent conifer trees have a very low rate of SOC stock change, with a negative rate of SOC stock change during the second decade (Fig. 4a). In the 20-40 cm soil depth, the patterns of SOC dynamics for two of the three tree species are insignificantly different from that of the top soil depth; however, sempervirent broadleaved trees have a significantly greater rate of SOC stock change than sempervirent conifer trees during the first decade following afforestation (Fig. 4b). In the $40-60 \mathrm{~cm}$ soil depth, all the tree species generally show a negative rate of SOC stock change in the first 10 years (Fig. 4c). For the older plantations (age group of 20-30 years), sempervirent broadleaved trees show a significantly greater rate of SOC stock change than the other two tree species. However, considering the relatively small number of observations for plantations older than 30 years, these results can only be considered tentative.

\subsection{Temporal changes in SOC stocks after afforestation with different tree species}

Temporal patterns of SOC stock change of different tree species also differ. In the $0-20 \mathrm{~cm}$ soil depth, the relationship between SOC stock change and plantation age of deciduous broadleaved trees is $\Delta \mathrm{Cs}=0.3 \times \Delta \mathrm{Age}-0.56\left(R^{2}=0.237, P<0.001\right)$; for
Fig. 4 The effect of plantation age group on the rate of SOC stock change of different tree species at soil depths of a $0-20$ $\mathrm{cm}, \mathbf{b} 20-40 \mathrm{~cm}$ and c $40-60 \mathrm{~cm}$. Dots with error bars denote the overall rate of SOC stock change and the $95 \%$ confidence interval. The number of observations is indicated in parentheses. A different letter at the top of the bars indicates a difference significant at the $P<0.05$ level

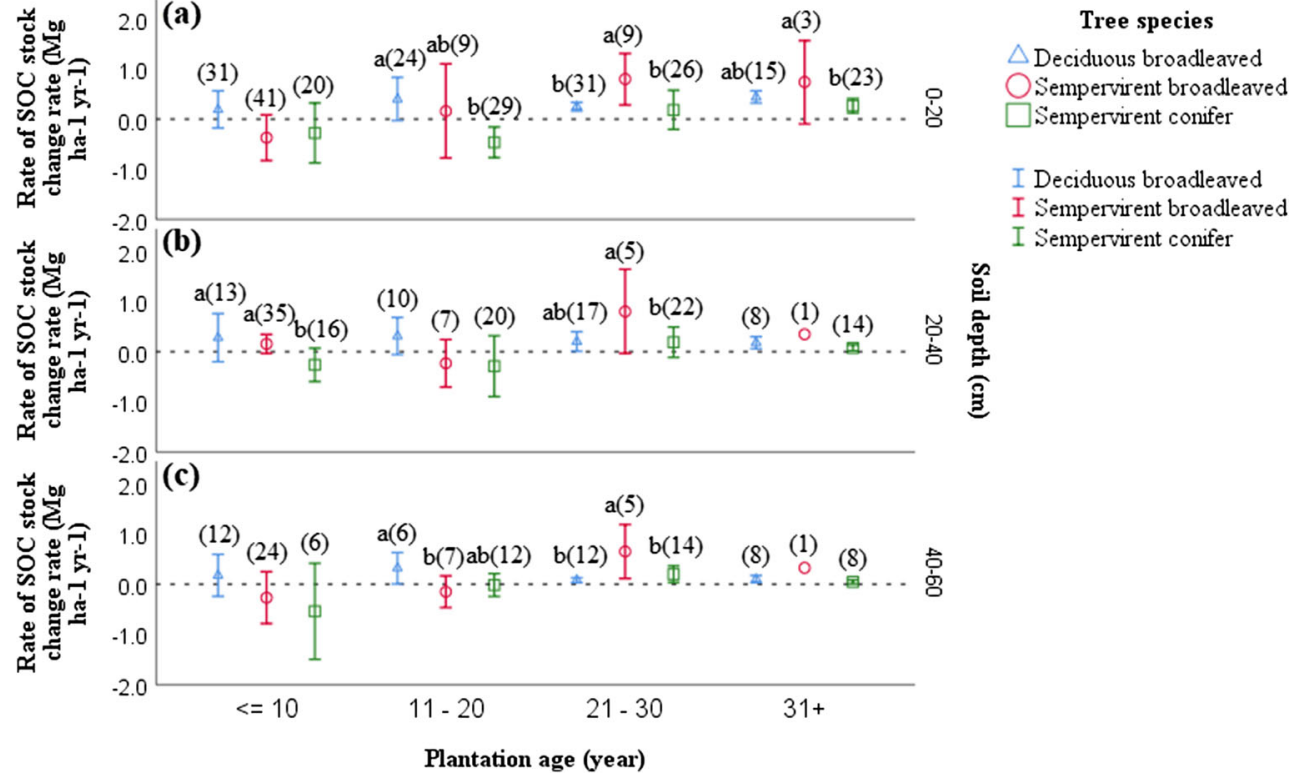


sempervirent broadleaved trees, it is $\Delta \mathrm{Cs}=0.85 \times \Delta$ Age -5.83 $\left(R^{2}=0.392, P<0.001\right)$; and for sempervirent conifer trees, it is $\Delta \mathrm{Cs}=0.29 \times \Delta \mathrm{Age}-5.49\left(R^{2}=0.175, P<0.001\right)$ (Fig. 5a). Sempervirent broadleaved trees show a greater rate of SOC stock change at $0.85 \mathrm{Mg} \mathrm{ha}^{-1}$ year $^{-1}$ at the topsoil, much higher than deciduous hardwood and sempervirent conifer trees (0.3 and $0.29 \mathrm{Mg} \mathrm{ha}^{-1}$ year $^{-1}$, respectively). However, while the SOC stock of deciduous broadleaved trees begins to accumulate after 2 years of afforestation, the increase in SOC contents of sempervirent trees lags behind several years ( 7 years for sempervirent broadleaved trees, 19 years for sempervirent conifer trees). In the deeper soils, there are no clear patterns between SOC stock change and plantation age for deciduous broadleaved trees and sempervirent conifer trees. However, SOC stock of sempervirent broadleaved trees shows a strong linear relationship with plantation age $(P$ $<0.001$ ) (Fig. 5b and c).

\subsection{Factors affecting SOC stocks after afforestation}

Pearson correlation analysis shows that the rate of SOC stock change in the topsoil is significantly negatively correlated with initial SOC stocks, temperature and precipitation (Table 3 ). The correlation is also significantly negative with the initial SOC stocks and precipitation in the $20-40 \mathrm{~cm}$ depth and with temperature in the $40-60 \mathrm{~cm}$ depth. On the other hand, for deciduous broadleaved trees, a significantly positive relationship is observed between the rate of SOC stock change and initial SOC stocks in the $20-40 \mathrm{~cm}$ depth, and the relationship is significantly positive between the rate of SOC stock change and precipitation in the $40-60 \mathrm{~cm}$ depth. However, for sempervirent broadleaved trees, there is a significantly negative relationship between the rate of SOC stock change and precipitation in the $40-60 \mathrm{~cm}$ depth. For sempervirent conifer trees, a significantly negative
Fig. 5 Linear regression between SOC stock and plantation age against different tree species at soil depths of a $0-20 \mathrm{~cm}, \mathbf{b} 20-40$ $\mathrm{cm}$ and c $40-60 \mathrm{~cm}$
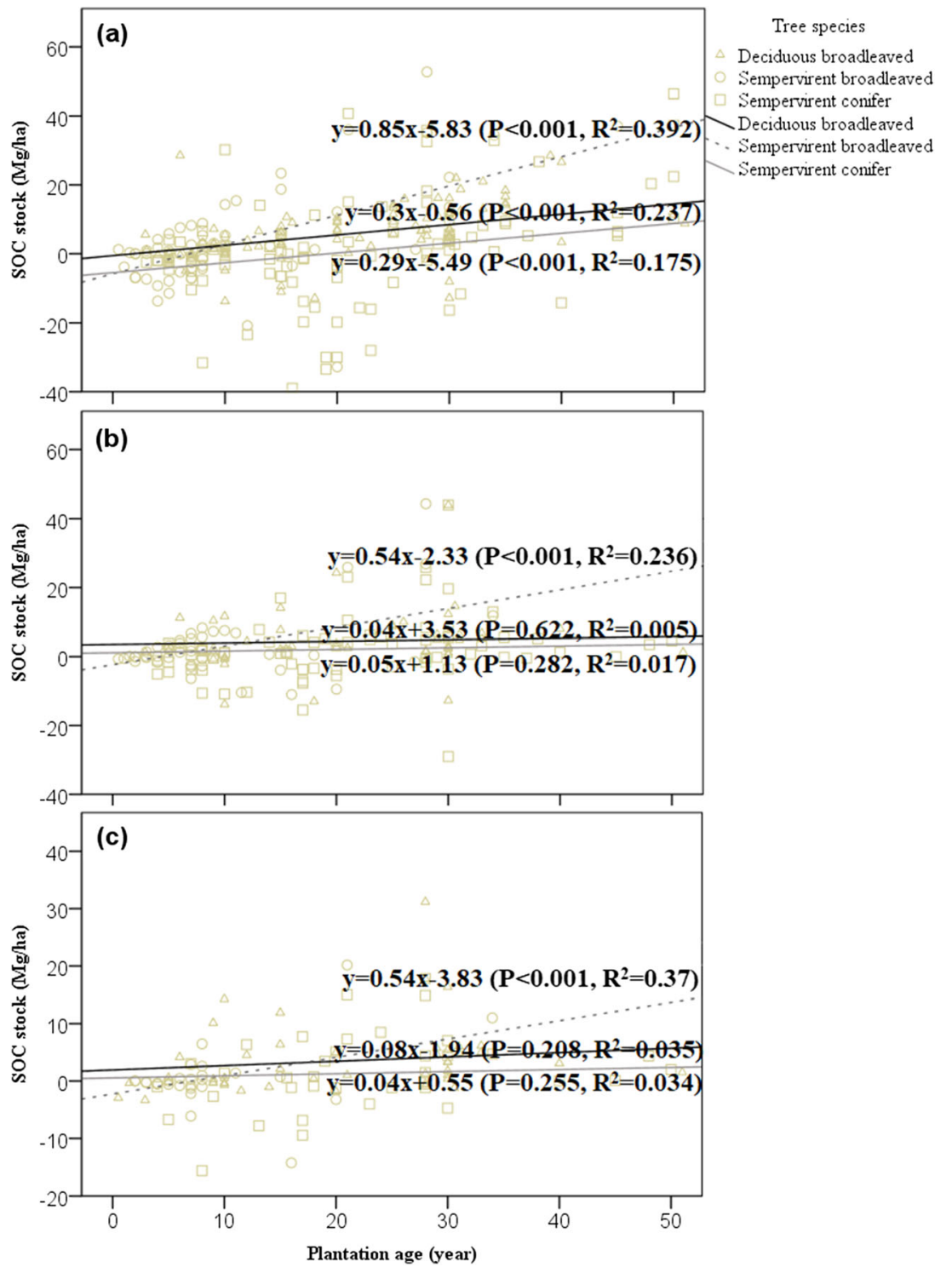
relationship is observed between the rate of SOC stock change and initial SOC stock across the three soil depths. The rate is also significantly correlated to precipitation in a negative way in the topsoil (Table 3).

Although the main contributing factors for $\Delta \mathrm{Cs}$ values varies in different soil depths and by various tree species, plantation age and initial SOC stock are the main influencing factors in the topsoil, while initial SOC stock is the main factor in deeper soil (Table 4). However, this trend is most strongly observed with sempervirent conifer trees. SOC stock change of sempervirent broadleaved trees is more closely related to plantation age, except for the middle depth $(20-40 \mathrm{~cm})$, where both plantation age and initial SOC stock play an important role. On the other hand, for deciduous broadleaved trees, the initial SOC stock has no significant relationship with changes in SOC stock: plantation age dominates the changes in the 0 $20 \mathrm{~cm}$ soil depth, while climatic conditions start having significant effects on SOC stock changes in the deeper soil depths (Table 4). Specifically, temperature has a significantly negative effect on the SOC stock, whereas precipitation has a positive effect.

\section{Discussion}

\subsection{Effects of tree species on SOC changes considering previous land use and plantation age}

The type of tree species has a profound effect on SOC stock changes since tree litterfall and roots are the main sources of SOC inputs. Both the quantity and quality of litter and living roots are related to tree traits (Gill and Jackson 2000; Cornwell et al. 2008; Kooch et al. 2019; Olsson et al. 2019; Cao et al. 2020). The rate of SOC stock change of deciduous broadleaved trees is significantly higher than that of sempervirent broadleaved and conifer trees in the 0 $20 \mathrm{~cm}$ soil depth (Fig. 2). This is because annual aboveground litter production is greater in deciduous forests than in sempervirent forests (Gobat et al. 2004; Liu et al. 2017), especially for young stands. The less significant differences at greater soil depths may be because aboveground litter only causes significant changes in the SOC pool in the topsoil (Cao et al. 2020). Nevertheless, leaching of SOC from litter into soils is a source of subsoil SOC inputs (Cleveland and Townsend 2006). Therefore, probably due to a combined effect of larger amount of litterfall and roots on SOC inputs, deciduous broadleaved trees show a significantly higher rate of SOC stock change than sempervirent conifer trees in the 20-40 cm soil depth (Gobat et al. 2004; Liu et al. 2014). In the 40-60 cm soil depth, the rates of SOC stock change of these three tree types are similar. This is probably because most soil samples from the 40-60 cm depth were obtained from relatively young plantations (average age 20 years). Young trees only have small roots which result in less SOC in deeper layers; as trees age, SOC increases in greater soil depths due to the development of the roots (Chen et al. 2013).

Generally, SOC stock can be increased by converting cropland to forest (Guo and Gifford 2002; Laganiere et al. 2010; Poeplau et al. 2011). However, the interaction between tree species and previous land use has a significant effect on SOC stock change. Our study shows a significant decrease of SOC stocks on the afforested cropland with sempervirent broadleaved trees at the $0-20 \mathrm{~cm}$ soil depth (Fig. 3a). This is probably because of the rapid decomposition of topsoil SOC and lower input of $\mathrm{C}$ from sempervirent broadleaved litter (Gobat et al. 2004; Lukac and Godbold 2011). Two different trends have been found regarding SOC change dynamics of grassland converted to forest (reviewed in the introduction). Our synthesis finds that the tree species affects SOC stock change rates following grassland afforestation, in different soil

Table 3 Pearson correlation coefficients between the rate of SOC stock change and influencing factors

\begin{tabular}{|c|c|c|c|c|c|}
\hline & Soil depth & Initial SOC stock & Mean annual temperature & Mean annual precipitation & $N$ \\
\hline \multirow[t]{3}{*}{ Total } & $0-20$ & $-0.296 * *$ & $-0.127 *$ & $-0.252 * *$ & 261 \\
\hline & $20-40$ & $-0.413^{* *}$ & -0.06 & $-0.172 *$ & 168 \\
\hline & $40-60$ & -0.164 & $-0.185^{*}$ & -0.075 & 115 \\
\hline \multirow[t]{3}{*}{ Deciduous broadleaved } & $0-20$ & 0.135 & -0.051 & 0.08 & 101 \\
\hline & $20-40$ & $0.289 *$ & -0.203 & 0.24 & 48 \\
\hline & $40-60$ & -0.109 & 0.219 & $0.529^{* *}$ & 38 \\
\hline \multirow[t]{3}{*}{ Sempervirent broadleaved } & $0-20$ & -0.08 & 0.103 & -0.057 & 62 \\
\hline & $20-40$ & -0.026 & -0.114 & -0.151 & 48 \\
\hline & $40-60$ & 0.168 & $-0.369 *$ & 0.01 & 37 \\
\hline \multirow[t]{3}{*}{ Sempervirent conifer } & $0-20$ & $-0.511^{* *}$ & -0.09 & $-0.399 * *$ & 98 \\
\hline & $20-40$ & $-0.611^{* *}$ & -0.005 & -0.226 & 72 \\
\hline & $40-60$ & $-0.471 * *$ & -0.022 & 0.02 & 40 \\
\hline
\end{tabular}

$*$ and ** indicate that correlation is significant at the 0.05 level (2-tailed) and 0.01 level (2-tailed), respectively 
Table 4 Stepwise regression to detect factors (T, P, A and I) determining SOC stock changes following afforestation

\begin{tabular}{|c|c|c|c|c|c|}
\hline Plant classification & Soil depth & Equation & $R^{2}$ & Sig. $(P)$ & $N$ \\
\hline \multirow[t]{3}{*}{ Total } & $0-20$ & $\Delta \mathrm{Cs}=0.274 \mathrm{~A}-0.181 \mathrm{I}+3.876$ & 0.235 & $0.000 * *$ & 261 \\
\hline & $20-40$ & $\Delta \mathrm{Cs}=-0.305 \mathrm{I}+8.002$ & 0.161 & $0.000 * *$ & 168 \\
\hline & $40-60$ & $\Delta \mathrm{Cs}=-0.115 \mathrm{I}+3.632$ & 0.038 & $0.038 *$ & 115 \\
\hline \multirow[t]{3}{*}{ Deciduous broadleaved } & $0-20$ & $\Delta \mathrm{Cs}=0.297 \mathrm{~A}-0.56$ & 0.237 & $0.001 * *$ & 101 \\
\hline & $20-40$ & $\Delta \mathrm{Cs}=-2.455 \mathrm{~T}+0.039 \mathrm{P}+3.313$ & 0.294 & $0.000 * *$ & 48 \\
\hline & $40-60$ & $\Delta \mathrm{Cs}=0.015 \mathrm{P}-4.876$ & 0.199 & $0.005 * *$ & 38 \\
\hline \multirow[t]{3}{*}{ Sempervirent broadleaved } & $0-20$ & $\Delta \mathrm{Cs}=0.85 \mathrm{~A}-5.829$ & 0.392 & $0.000 * *$ & 62 \\
\hline & $20-40$ & $\Delta \mathrm{Cs}=0.672 \mathrm{~A}-0.271 \mathrm{I}+1.494$ & 0.318 & $0.000 * *$ & 48 \\
\hline & $40-60$ & $\Delta \mathrm{Cs}=0.538 \mathrm{~A}-3.83$ & 0.37 & $0.000 * *$ & 37 \\
\hline \multirow[t]{3}{*}{ Sempervirent conifer } & $0-20$ & $\Delta \mathrm{Cs}=0.204 \mathrm{~A}-0.253 \mathrm{I}+7.786$ & 0.37 & $0.000 * *$ & 98 \\
\hline & $20-40$ & $\Delta \mathrm{Cs}=-0.471 \mathrm{I}+11.23$ & 0.336 & $0.000 * *$ & 72 \\
\hline & $40-60$ & $\Delta \mathrm{Cs}=-0.156 \mathrm{I}+4.061$ & 0.109 & $0.038 *$ & 40 \\
\hline
\end{tabular}

$\triangle \mathrm{Cs}$ is SOC stock change following afforestation; $\mathrm{T}\left({ }^{\circ} \mathrm{C}\right)$ is the mean annual temperature; $\mathrm{P}(\mathrm{mm})$ is the mean annual precipitation; A (year) is the plantation age; $\mathrm{I}\left(\mathrm{Mg} \mathrm{ha}^{-1}\right)$ is the initial SOC stock

$*$ and $* *$ indicate significant difference at the 0.05 level $(P<0.05)$ and 0.01 level $(P<0.01)$, respectively

layers (Fig. 3b). Deciduous broadleaved trees have a higher rate of SOC stock change than other species in the topsoil because they produce litter that decomposes faster, and the SOC inputs from tree litter is substantially greater than that from grass (Cornwell et al. 2008). Sempervirent conifer trees produce litter that contains more lignin, which decomposes slower (Lukac and Godbold 2011). For this reason, SOC input is lower than that for grass, and grassland afforestation with sempervirent conifer trees leads to a loss of SOC.

Although there is a loss of SOC stock during the first few years after afforestation, SOC gradually increases again as the plantation ages. Studies have reported different plantation ages during which SOC accumulation changes $\mathrm{C}$ dynamics (reviewed in the introduction). Our synthesis shows that SOC change dynamics with age groups are different among the three tree species (Fig. 4). In soil depths of $0-20 \mathrm{~cm}$ and 20 $40 \mathrm{~cm}$, deciduous broadleaved trees have more SOC stock when it is younger than 20 , because its litter quantity is greater and its decomposition rate is faster than that of young sempervirent trees (Gobat et al. 2004; Cornwell et al. 2008; Olsson et al. 2019). That is also why deciduous broadleaved trees can sequester SOC at a steady rate without a decrease in SOC stock in the initial years. However, sempervirent broadleaved trees show greater SOC stock after the first two decades. It is probably because mature sempervirent broadleaved trees (1) have more litter fall to contribute as C inputs into soils than the young stands; (2) maintain denser foliage during the whole year, thereby reducing negative effects of high temperature and precipitation on SOC stock (Gill and Jackson 2000). Root litter and exudates were the main resources contributing to deeper soil carbon input (Rasse et al. 2005). Deciduous broadleaved trees and sempervirent broadleaved trees show a greater SOC stock than sempervirent conifer in deeper soil layers for older stands, possibly owing to a higher belowground biomass generated by the larger and more deeply anchored root systems of broadleaved trees (Strong and La Roi 1983; Jobbágy and Jackson 2000; Liu et al. 2014). Such differences increase with increasing plantation age.

\subsection{Management implications}

Afforestation has been recognised as an effective method to increase SOC stock and alleviate soil degradation (Hou et al. 2019b). Nonetheless, the consequences of the relationship between plantation age and tree species on the rate of SOC stock change are still not well understood. During the initial stages, trees have little impact on the soil, and the legacy of previous land use in terms of soil microbial activities, physical soil properties, availability of soil nutrients, etc., play a major role. As forests develop, input of SOC from litterfall increases until it stabilises approximately 20-30 years after afforestation (Bárcena et al. 2014). Our synthesis suggests that deciduous broadleaved trees show a greater and more stable increase of SOC stock than sempervirent broadleaved trees and sempervirent conifer trees during the first two decades. The increase of SOC stock begins just 2 years after afforestation with deciduous broadleaved trees, which indicates that this tree species may be a better choice to achieve a faster growth in SOC. Afforestation with sempervirent broadleaved trees experiences a loss of soil $\mathrm{C}$ in the first 7 years; however, sempervirent broadleaved trees show a greater increase of SOC stock than deciduous broadleaved trees and sempervirent conifer trees after 20 years. Sempervirent conifer trees have much slower and lower increase in SOC stock; only 19 years after afforestation is SOC higher than in year 0 , 
which indicates that sempervirent conifer trees are not a good tree type for short-term SOC accumulation.

Higher initial SOC stock is more susceptible to loss due to soil disturbances during planting of seedling (Shi et al. 2013). In addition, the priming effect is positively related to aboveground litter inputs. Initial high SOC content increases the activity of micro-organisms after afforestation, which in turn stimulates decomposition of existing SOC (Liu et al. 2019). In other words, lower increase in SOC stock may result from higher rate of decomposition in more nutrient-rich soils (Vesterdal et al. 2002). Our study shows a significant negative correlation between rate of SOC stock change and initial SOC contents in the $0-40 \mathrm{~cm}$ soil depth, which is in line with Zhang et al. (2010) and Shi et al. (2013). In addition, we find such correlations differ among the three tree species. The rate of SOC stock change of sempervirent trees are negatively related to initial $\mathrm{C}$ content, while deciduous broadleaved trees show significantly positive correlation between its rate of SOC stock change and initial $\mathrm{C}$ stocks. This is likely due to higher fungal richness in deciduous broadleaved soils than in the other tree soil types (Chen et al. 2019). The greater number of fungal communities in afforested deciduous broadleaved trees, together with high initial C stock, results in a higher rate of litter residue decomposition and rhizodeposition (Chen et al. 2019). Our study suggests that sempervirent trees may lead to SOC loss, when planted on soils with high initial SOC. However, sempervirent conifer trees can adapt to the nutrientpoor environment (Qin and Shangguan 2019). Therefore, it would be better to plant deciduous broadleaved trees to reduce soil disturbance of nutrient-rich soils and obtain greater increase in SOC stock, whereas sempervirent conifer afforestation is more suitable for nutrient-poor soils.

In terms of the effects of climatic conditions on the SOC stock changes, Zhang et al. (2010) and Shi et al. (2013) share the idea that temperature is negatively correlated with SOC stock, because high temperatures contribute to rapid SOC decomposition (Cleveland and Townsend 2006; Ding et al. 2019; Wehr et al. 2020). However, precipitation also affects SOC stock in two aspects. On the one hand, high rainfall increases topsoil moisture, which in turn quickens litterfall decomposition (Olsson et al. 2019). On the other hand, the leaching effect of SOC is positively related to rainfall (Cleveland and Townsend 2006). In light of the new classification of tree species, our synthesis provides evidence of the different effects of rainfall on SOC stock. Sempervirent conifer trees show a significantly negative relationship between the rate of SOC stock change and precipitation in the 0 $20 \mathrm{~cm}$ soil depth. Considering the low decomposition rate for litterfall of sempervirent conifer trees, rainfall plays a more important role in leaching SOC from the topsoil into the subsoil, than in affecting the litter decomposition rate. Deciduous broadleaved trees show positive correlations between the rate of SOC stock change and precipitation, because rainfall increases the decomposition rate of aboveground litter (Wehr et al. 2020). On the other hand, the leaching effect is marginal for deciduous broadleaved trees since its large foliage slows rainfall seepage (Cleveland and Townsend 2006). In what concerns sempervirent broadleaved trees, its rate of SOC stock change is mostly affected by plantation age rather than climatic conditions (Table 4). This is because (1) the litter production of sempervirent broadleaved trees, which is a major source of SOC input, increases substantially with stand ages; (2) sempervirent broadleaved trees are usually distributed in subtropical or tropical regions, where there is little variations in temperature and precipitation (Ge et al. 2017).

\subsection{Data constraints}

Not all studies included in this meta-analysis reported all the information we needed. In order to include as many studies as possible, some missing values were extrapolated or standardized (see Supporting Information for further explanation), which may add inaccuracy to our findings. We suggest that future studies include SOC data from subsoil layers. In addition, we are not able to include all the variables (e.g. soil type, clay content, nitrogen stock, $\mathrm{pH}$ value) in our synthesis due to insufficient data in most studies, which may result in the low variation of SOC stock changes explained by the present model. We suggest the future primary studies include the value for these factors when reporting the dynamic changes in SOC stock. Finally, some inaccuracies may result from using SOM values to estimate SOC values, and from using estimated $\mathrm{BD}$ values to estimate $\mathrm{SOC}$ values. However, only $9 \%$ of the SOC values used in our analysis are calculated using SOM value and estimated $\mathrm{BD}$ values. We trust that the results we obtain are accurate. One further limitation of this study is that $95 \%$ of the studies we reviewed had no observations of the SOC stock change after afforestation for plantations older than 50 years. This could make our results tentative for older stands.

\section{Conclusions}

Tree species have an important impact on changes in SOC stock after afforestation. This study investigates SOC stock change after afforestation and the influencing factors of tree species, grouped as deciduous broadleaved, sempervirent broadleaved and sempervirent conifer. Deciduous broadleaved trees show a quicker and more stable increase in SOC stock after afforestation, with SOC stock increasing starting from the third year of afforestation. It is especially suited for afforestation of grassland or soils with high initial SOC. Sempervirent broadleaved afforestation results in a loss in SOC stock in young stands, but greater increase in SOC stock in mature stands. Sempervirent conifer afforestation 
shows the lowest rate of SOC stock change, but is suitable for nutrient-poor soil. High initial SOC stocks negatively influence the rate of SOC stock change of sempervirent trees, but positively influence that of deciduous broadleaved trees. The effects of temperature and precipitation on SOC stock changes are minimal for sempervirent trees, whereas precipitation is positively related to the SOC stock of deciduous broadleaved trees in deeper soil depths. The results emphasize the importance of considering tree species when estimating the SOC sequestration potential of afforestation programs.

Authors' contributions All authors contributed to the design and development of this manuscript. G.H. carried out the research, analysed the data and prepared the first draft of the manuscript. C.D. and X.L. revised and edited the manuscript. L.G. helped to collect data from Chinese literature.

Funding The work described in this paper has been fully supported by a grant from the Research Grants Council of the Hong Kong Special Administrative Region, China (project No. 12305116).

Data availability All data generated or analysed during this study are included in this published article.

\section{Compliance with ethical standards}

Conflict of interest The authors declare that they have no conflict of interest.

Disclaimer The sponsors had no role in the design, execution, interpretation or writing of the study.

\section{References}

Angers DA, Eriksen-Hamel NS (2008) Full-inversion tillage and organic carbon distribution in soil profiles: a meta-analysis. Soil Sci Soc Am J 72:1370-1374

Bárcena TG, Kiær LP, Vesterdal L, Stefánsdóttir HM, Gundersen P, Sigurdsson BD (2014) Soil carbon stock change following afforestation in Northern Europe: a meta-analysis. Glob Chang Biol 20: 2393-2405

Bormann H, Klaassen K (2008) Seasonal and land use dependent variability of soil hydraulic and soil hydrological properties of two Northern German soils. Geoderma 145:295-302

Cao J, He X, Chen Y, Chen Y, Zhang Y, Yu S, Zhou L, Liu Z, Zhang C, $\mathrm{Fu} \mathrm{S}$ (2020) Leaf litter contributes more to soil organic carbon than fine roots in two 10-year-old subtropical plantations. Sci Total Environ 704:135341

Chen GS, Yang ZJ, Gao R, Xie JS, Guo JF, Huang ZQ, Yang YS (2013) Carbon storage in a chronosequence of Chinese fir plantations in southern China. For Ecol Manag 300:68-76

Chen L, Xiang W, Wu H, Ouyang S, Lei P, Hu Y, Ge T, Ye J, Kuzyakov Y (2019) Contrasting patterns and drivers of soil fungal communities in subtropical deciduous and evergreen broadleaved forests. Appl Microbiol Biotechnol 103:5421-5433

Cleveland CC, Townsend AR (2006) Nutrient additions to a tropical rain forest drive substantial soil carbon dioxide losses to the atmosphere. Proc Natl Acad Sci 103:10316-10321

Cornwell WK, Cornelissen JH, Amatangelo K, Dorrepaal E, Eviner VT, Godoy O, Hobbie SE, Hoorens B, Kurokawa H, Harguindeguy NP,
Quested HM, Santiago LS, Wardle DA, Wright IJ, Aerts R, Allison SD, Bodegom P, Brovkin V, Chatain A, Callaghan TV (2008) Plant species traits are the predominant control on litter decomposition rates within biomes worldwide. Ecol Lett 11:1065-1071

De Deyn GB, Cornelissen JH, Bardgett RD (2008) Plant functional traits and soil carbon sequestration in contrasting biomes. Ecol Lett 11: $516-531$

Deng L, Shangguan ZP, Sweeney S (2014) “Grain for Green" driven land use change and carbon sequestration on the Loess Plateau, China. Scientific reports, 4

Di Iorio A, Lasserre B, Scippa GS, Chiatante D (2005) Root system architecture of Quercus pubescens trees growing on different sloping conditions. Ann Bot 95:351-361

Ding Y, Leppälammi-Kujansuu J, Helmisaari HS (2019) Fine root longevity and below-and aboveground litter production in a boreal Betula pendula forest. For Ecol Manag 431:17-25

Don A, Schumacher J, Freibauer A (2011) Impact of tropical land-use change on soil organic carbon stocks-a meta-analysis. Glob Chang Biol 17:1658-1670

Eclesia RP, Jobbagy EG, Jackson RB, Biganzoli F, Piñeiro G (2012) Shifts in soil organic carbon for plantation and pasture establishment in native forests and grasslands of South America. Glob Chang Biol 18:3237-3251

Ge J, Berg B, Xie Z (2017) Leaf habit of tree species does not strongly predict leaf litter decomposition but alters climate-decomposition relationships. Plant Soil 419:363-376

Gill RA, Jackson RB (2000) Global patterns of root turnover for terrestrial ecosystems. New Phytologist 147:13-31

Gobat JM, Aragno M, Matthey W (2004) The living soil: fundamentals of soil science and soil biology. Science Publishers

Guo LB, Gifford RM (2002) Soil carbon stocks and land use change: a meta-analysis. Glob Chang Biol 8:345-360

Hiederer R, Köchy M (2011) Global Soil Organic Carbon Estimates and the Harmonized World Soil Database. EUR 25225 EN. Publications Office of the European Union. 79

Hou G, Delang CO, Lu X, Gao L (2019a) Soil organic carbon storage varies with stand ages and soil depths following afforestation. Annals Forest Res 62:3-20

Hou G, Delang CO, Lu X, Olschewski R (2019b) Valuing carbon sequestration to finance afforestation projects in China. Forests 10:754

Hou G, Delang CO, Lu X (2020a) Afforestation changes soil organic carbon stocks on sloping land: the role of previous land cover and tree type. Ecol Eng 152:105860. https://doi.org/10.1016/j.ecoleng. 2020.105860

Hou G, Delang CO, Lu X, Gao L (2020b) Grouping tree species to estimate afforestation-driven soil organic carbon sequestration. Plant Soil 1-12

IPCC (2007) Revised IPCC Guidelines for National Greenhouse Gas Inventories. Intergovernmental Panel on Climate Change Publication. Cambridge University Press, Cambridge

Jobbágy EG, Jackson RB (2000) The vertical distribution of soil organic carbon and its relation to climate and vegetation. Ecol Appl 10: 423-436

Kooch Y, Sanji R, Tabari M (2019) The effect of vegetation change in C and $\mathrm{N}$ contents in litter and soil organic fractions of a Northern Iran temperate forest. Catena 178:32-39

Laganiere J, Angers DA, Pare D (2010) Carbon accumulation in agricultural soils after afforestation: a meta-analysis. Glob Chang Biol 16: 439-453

Lal R (2006) Enhancing crop yields in the developing countries through restoration of the soil organic carbon pool in agricultural lands. Land Degrad Dev 17:197-209

Lal R (2015) Restoring soil quality to mitigate soil degradation. Sustainability 7:5875-5895

Lal R (2018) Climate change and the global soil carbon stocks. In Soil and Climate (pp. 419-426). CRC Press 
Li D, Niu S, Luo Y (2012) Global patterns of the dynamics of soil carbon and nitrogen stocks following afforestation: a meta-analysis. New Phytol 195:172-181

Li Z, Liu C, Dong Y, Chang X, Nie X, Liu L, Xiao H, Lu Y, Zeng G (2017) Response of soil organic carbon and nitrogen stocks to soil erosion and land use types in the Loess hilly-gully region of China. Soil Tillage Res 166:1-9

Liu C, Xiang W, Lei P, Deng X, Tian D, Fang X, Peng C (2014) Standing fine root mass and production in four Chinese subtropical forests along a succession and species diversity gradient. Plant Soil 376: 445-459

Liu X, Yang T, Wang Q, Huang F, Li L (2017) Dynamics of soil carbon and nitrogen stocks after afforestation in arid and semi-arid regions: a meta-analysis. Sci Total Environ 618:1658-1664

Liu X, Lin TC, Vadeboncoeur MA, Yang Z, Chen S, Xiong D, Xu C, Li Y, Yang Y (2019) Root litter inputs exert greater influence over soil $\mathrm{C}$ than does aboveground litter in a subtropical natural forest. Plant Soil 444:489-499

Lukac M, Godbold DL (2011) Soil ecology in northern forests: a belowground view of a changing world. Cambridge University Press

Luyssaert S, Schulze ED, Börner A, Knohl A, Hessenmöller D, Law BE, Ciais P, Grace J (2008) Old-growth forests as global carbon sinks. Nature 455:213-215

Mann LK (1986) Changes in soil carbon storage after cultivation. Soil Sci 142:279-288

Nave LE, Swanston CW, Mishra U, Nadelhoffer KJ (2013) Afforestation effects on soil carbon storage in the United States: a synthesis. Soil Sci Soc Am J 77:1035-1047

Olsson BA, Guedes BS, Dahlin AS, Hyvönen R (2019) Predicted longterm effects of decomposition of leaf litter from Pinus taeda, Eucalyptus cloeziana and deciduous miombo trees on soil carbon stocks. Glob Ecol Conserv 17:e00587

Paul KI, Polglase PJ, Nyakuengama JG, Khanna PK (2002) Change in soil carbon following afforestation. For Ecol Manag 168:241-257

Pérez-Cruzado C, Mansilla-Salinero P, Rodríguez-Soalleiro R, Merino A (2012) Influence of tree species on carbon sequestration in afforested pastures in a humid temperate region. Plant Soil 353: 333-353

Poeplau C, Don A, Vesterdal L, Leifeld J, Van Wesemael BAS, Schumacher J, Gensior A (2011) Temporal dynamics of soil organic carbon after land-use change in the temperate zone-carbon response functions as a model approach. Glob Chang Biol 17:2415-2427
Post WM, Kwon KC (2000) Soil carbon sequestration and land-use change: processes and potential. Glob Chang Biol 6:317-327

Qin J, Shangguan Z (2019) Effects of forest types on leaf functional traits and their interrelationships of Pinus massoniana coniferous and broad-leaved mixed forests in the subtropical mountain, Southeastern China. Ecol Evol 9:6922-6932

Rasse DP, Rumpel C, Dignac MF (2005) Is soil carbon mostly root carbon? Mechanisms for a specific stabilisation. Plant Soil 269: 341-356

Sakin E (2012) Organic carbon organic matter and bulk density relationships in arid-semi arid soils in Southeast Anatolia region. Afr J Biotechnol 11:1373-1377

Shi S, Zhang W, Zhang P, Yu Y, Ding F (2013) A synthesis of change in deep soil organic carbon stores with afforestation of agricultural soils. For Ecol Manag 296:53-63

Song X, Peng C, Zhou G, Jiang H, Wang W (2014) Chinese grain for green program led to highly increased soil organic carbon levels: a meta-analysis. Sci Rep 4:4460

Stockmann U, Adams MA, Crawford JW, Field DJ, Henakaarchchi N, Jenkins M, Minasny B, McBratney AB, Wheeler I (2013) The knowns, known unknowns and unknowns of sequestration of soil organic carbon. Agric Ecosyst Environ 164:80-99

Strong WL, La Roi G (1983) Root-system morphology of common boreal forest trees in Alberta, Canada. Can J For Res 13:1164-1173

Vesterdal L, Ritter E, Gundersen P (2002) Change in soil organic carbon following afforestation of former arable land. For Ecol Manag 169: $137-147$

Wehr JB, Lewis T, Dalal RC, Menzies NW, Verstraten L, Swift S, Bryant P, Tindale N, Smith TE (2020) Soil carbon and nitrogen pools, their depth distribution and stocks following plantation establishment in south east Queensland, Australia. For Ecol Manag 457:117708

Wu H, Guo Z, Peng C (2003) Land use induced changes of organic carbon storage in soils of China. Glob Chang Biol 9:305-315

Xiong X, Grunwald S, Myers DB, Ross CW, Harris WG, Comerford NB (2014) Interaction effects of climate and land use/land cover change on soil organic carbon sequestration. Sci Total Environ 493:974-982

Zhang K, Dang H, Tan S, Cheng X, Zhang Q (2010) Change in soil organic carbon following the 'Grain-for-Green' program in China. Land Degrad Dev 21:13-23

Publisher's note Springer Nature remains neutral with regard to jurisdictional claims in published maps and institutional affiliations. 